\title{
RIAP HUTAN TANAMAN JATI DAN CENDANA DI NUSA TENGGARA TIMUR
}

\author{
Increment of Jati (Tectona grandis) and Sandalwood (Santalum album) Plantation \\ in Nusa Tenggara Timur
}

I Wayan Widhiana Susila

Balai Penelitian Kehutanan Mataram

Jl. Dharma Bhakti No.7, PO. BOX 1054, Ds. Langko, Kec. Lingsar, Lombok Barat, NTB 83371 Telp. (0370) 6573874, Fax. (0370) 6573841

Naskah masuk : 18 April 2008 ; Naskah diterima : 26 Februari 2009

\begin{abstract}
Jati (Tectona grandis) and sandalwood (Santalum album) are species grown under plantation forest programes in Timor. However, quantitative information about its stand growth is still lacking. Therefore, the research was aimed at obtaining information on stand growth as well as growth and yield models sustainable stand management. The research of jati was conducted at Timor (two locations), and at Alor (for sandalwood). Observation of jati was done every year since 1997 to 2004, and sandalwood since 2004 to 2006 on three permanent measurement plots (PMPs) of $50 \times 50 \mathrm{~m}$. The volume increment of jati age 10 years at Takari is $7,67 \mathrm{~m}^{3} \mathrm{ha}^{-1}$ year ${ }^{-1}$; stand of jati age 8 years at Polen is 1,96 $\mathrm{m}^{3} \mathrm{ha}^{-1}$ year $\mathrm{r}^{-1}$ and jati age 7 years is $2,27 \mathrm{~m}^{3} \mathrm{ha}^{-1}$ year ${ }^{-1}$. The volume increment of sandalwood age 31 years at Alor is $0,32 \mathrm{~m}^{3} \mathrm{ha}^{-1}$ year ${ }^{-1}$, dan stand of sandalwood age 19 years is 0,74 $\mathrm{m}^{3} \mathrm{ha}^{-1}$ year $\mathrm{r}^{-1}$. The estimation models of jati at Takari are $D(\mathrm{~cm})=5.5236+0.0871^{X}$ and $T(\mathrm{~m})=$ $2.3149+0.1846^{X}$, the models at Polen in 1997 are $D(\mathrm{~cm})=2.2515+0.1909^{X}$ and $T(\mathrm{~m})=2.3379+$ $0.1517^{X}$. The estimation models of sandalwood in 1976 at Alor are $D(\mathrm{~cm})=6,5412+0,0192^{X}$ dan $\log T(m)=\log -14,6848+6,0541 \log X$, and sandalwood in 1987 are $D(\mathrm{~cm})=6,9839+0,2140 X$ , 2) $\log T(m)=\log -4,4230+3,6507 \log X$. Where: a) $D$ and $T=$ diameter and height of stand. and b) $x=$ age of stand.
\end{abstract}

Key words : stand of jati, volume increment, the estimation models, Timor and Alor

\begin{abstract}
ABSTRAK
Jenis jati (Tectona grandis) dan cendana (Santalum album) merupakan komoditi yang banyak dikembangkan pada program hutan tanaman selama ini di Timor. Akan tetapi, informasi kuantitatif keberhasilan kedua jenis tanaman tersebut masih relatif kurang, seperti misalnya data riap tegakan. Penelitian ini bertujuan memperoleh informasi riap dan model pertumbuhan untuk pengelolaan tegakan yang lestari. Penelitian jati dilaksanakan di Timor (2 lokasi) pada tahun $1997-2004$ dan cendana di Alor pada tahun 2004 - 2006 dengan pembuatan dan pengukuran masing-masing petak ukur permanen (PUP) pada setiap lokasi ukuran $3 \times 50 \times 50 \mathrm{~m}$. Pengukuran/pengamatan ulangan dilakukan setiap tahun pada bulan yang sama. Riap volume tegakan jati umur 10 tahun di Takari adalah $7,67 \mathrm{~m}^{3} \mathrm{ha}^{-1}$ tahun $^{-1}$; tegakan jati di Polen pada umur 8 tahun adalah $1,96 \mathrm{~m}^{3} \mathrm{ha}^{-1}$ tahun ${ }^{-1}$, dan tegakan umur 7 tahun adalah 2,27 $\mathrm{m}^{3} \mathrm{ha}^{-1}$ tahun $^{-1}$. Riap volume tegakan cendana di Alor pada umur 31 tahun adalah $0,32 \mathrm{~m}^{3} \mathrm{ha}^{-1}$ tahun $^{-1}$, dan tegakan umur 19 tahun adalah $0,74 \mathrm{~m}^{3} \mathrm{ha}^{-1}$ tahun ${ }^{-1}$. Model penduga tegakan jati di Takari adalah 1) $\mathrm{D}(\mathrm{cm})=5,52356+0,08710^{\mathrm{X}}$, dan 2) $\mathrm{T}(\mathrm{m})=2,31488+$ $0,18455^{\mathrm{X}}$ dan jati di Polen tahun 1997 adalah 1) $\mathrm{D}(\mathrm{cm})=2,25149+0,19089^{\mathrm{x}}$, dan 2) $\mathrm{T}(\mathrm{m})=2,33788$ $+0,15172^{\mathrm{X}}$. Model penduga tegakan cendana tahun 1976 adalah 1) $\left.\mathrm{D}(\mathrm{cm})=6,5412+0,0192^{\mathrm{X}}, 2\right)$ $\log \mathrm{T}(\mathrm{m})=\log -14,6848+6,0541 \log \mathrm{X}$, dan cendana tahun 1987 adalah 1) $\mathrm{D}(\mathrm{cm})=6,9839+$
\end{abstract}


$0,2140 X, 2) \log T(m)=\log -4,4230+3,6507 \log X$. Dimana $:$ a) $X=$ umur tegakan, $b) D=$ diameter tegakan, dan c) $\mathrm{T}=$ tinggi tegakan.

\section{Kata kunci : tegakan jati, tegakan cendana, riap volume tegakan, model penduga, Timor dan Alor}

\section{PENDAHULUAN}

Jati (Tectona grandis L.f.) dan cendana (Santalum album Linn) adalah jenis-jenis unggulan Nusa Tenggara Timur yang bernilai ekonomi relatif tinggi. Selama ini dalam kegiatan kehutanan melalui program reboisasi, hutan tanaman industri (HTI) dan hutan kemasyarakatan kedua jenis tersebut selalu direkomendasikan untuk dikembangkan.

Jati sangat diminati masyarakat karena kayunya mempunyai keunggulan yang tidak dimiliki oleh jenis lain, yaitu termasuk kayu kelas I, kuat, awet, dan mudah dikerjakan, memiliki penampilan yang menarik (dekoratif) dan nilai jualnya tinggi (Anonim, 1994 dalam Darma, 2004). Jenis ini termasuk salah satu jenis tanaman yang tahan kekeringan karena memiliki mekanisme tersendiri untuk menghadapi kekurangan air yaitu dengan cara menggugurkan daun pada musim kemarau dan akan segera bertunas di musim hujan. Jati juga memiliki sistem perakaran yang dalam dan ekstensif sehingga sangat cocok dikembangkan di lahan kering karena mampu menyerap hara dan air sampai ke lapisan tanah yang sangat dalam.

Cendana menghasilkan produk kayu dan minyak atsiri (dari produk teras) yang bernilai ekonomis tinggi. Kayunya dapat digunakan untuk bahan kerajinan (patung, dupa, kipas) dan bahan bangunan suci dan minyak atsiri yang dihasilkan digunakan sebagai bahan obat-obatan dan parfum. Di Indonesia tanaman cendana termasuk salah satu tanaman yang dilindungi karena keberadaannya sudah langka atau dapat dikatakan hampir punah. Faktor-faktor penyebab langkanya cendana antara lain karena adanya: 1) keengganan masyarakat untuk menanam cendana, karena adanya peraturan daerah yang tidak mendukung, 2) kebakaran hutan, 3) penebangan liar (pencurian), dan 4) persyaratan hidup cendana yang rumit (Rahayu et al., 2002).

Pada beberapa tempat/lokasi hasil dari program kegiatan reboisasi dan HTI, kedua jenis yang dikembangkan ini tumbuhnya cukup berhasil, yaitu tegakan cendana pada kawasan hutan produksi di Alor Barat Laut Kabupaten Alor dan tegakan jati pada kawasan hutan produksi di Takari Kabupaten Kupang dan Polen Kabupaten Timor Tengah Selatan, yang merupakan lokasi kegiatan penelitian.

Keberhasilan pembangunan hutan tanaman atau tegakan jati dan cendana tersebut di atas perlu dikelola dengan manajemen yang baik (harus konsisten dengan prinsip-prinsip kelestarian) agar ke depan stabilitas dan kontinuitas produksi kayu tersebut akan terjaga/lestari. Informasi keberhasilan pembangunan hutan tanaman sering dilihat dari data kualitatifnya. Sedangkan data kuantitatifnya belum begitu banyak diketahui. Padahal dalam rencana pengelolaan hutan tanaman yang baik, informasi yang bersifat kuantitatif tersebut sangat diperlukan. Salah satu informasi yang penting adalah pengetahuan mengenai pertumbuhan riapnya.

Salah satu kewajiban pemerintah dalam mewujudkan keberhasilan program hutan tanaman adalah menyediakan informasi dan perangkat manajemen yang diperlukan oleh pengelola. Diantara perangkat yang mendasar yang harus disediakan ialah model-model pertumbuhan dan hasil (growth and yield models). Model ini nantinya bisa digunakan untuk memproyeksikan produksi tegakan pada berbagai kondisi tempat tumbuh dan berbagai alternatif perlakuan silvikultur. Ketersediaan perangkat ini memungkinkan para pengelola tegakan memperoleh informasi-informasi yang diperlukan dalam pengambilan keputusan manajemen jangka panjang seperti mengenai jarak tanam, kerapatan tegakan, rotasi ataupun jadwal pemungutan. 
Penelitian ini bertujuan untuk memperoleh perangkat pertumbuhan dan hasil yang diperlukan dalam pengelolaan hutan tanaman, khususnya tegakan jati dan cendana secara lestari. Untuk itu luaran penelitian ini adalah informasi riap dan model pertumbuhan tegakan tanaman jati dan cendana.

\section{BAHAN DAN METODE}

\section{A. Lokasi Penelitian}

Pembuatan dan pengukuran petak ukur permanen (PUP) tegakan dilaksanakan pada lokasi sebagai berikut :

1) Tegakan jati di lokasi Oesusu-Takari Kabupaten Kupang dan Kawasan Hutan Polen Kabupaten Timor Tengah Selatan

- Kawasan hutan Oesusu-Takari, termasuk kelompok hutan Sisimeni Sanam (RTK 183). Jarak tanam 3 x 3 m dan tahun tanam 1990/1991. Topografi bergelombang dengan ketiggian kurang lebih 200-250 m dpl. Data terkumpul dari lima kali pengamatan/ pengukuran dari tahun 1997 s/d 2001.

- Kawasan Hutan Polen Selatan pada tegakan tahun tanam 1995/1996 dan 1996/1997 dengan jarak tanam $3 \times 2 \mathrm{~m}$. Topografi datar sampai bergelombang dengan ketinggian tempat $340 \mathrm{~m}$ dpl. Data terkumpul dari tiga kali pengukuran dari tahun 2002 s/d 2004.

2) Tegakan cendana di Kecamatan Alor Barat Laut Kabupaten Alor, Kelompok Hutan Omtel/RTK1. Pembuatan PUP dilakukan pada dua lokasi tegakan cendana yaitu tahun tanam 1976 dan 1987 dengan masing-masing jarak tanam $3 \times 2 \mathrm{~m}$. Topografi lapangan kedua lokasi relatif sama yaitu datar sampai bergelombang. Tinggi tempat lokasi tahun tanam 1987 adalah $620 \mathrm{~m}$ dpl, sedangkan lokasi tahun tanam 1976 adalah $640 \mathrm{~m}$ dpl. Pengamatan/pengukuran pertama dilakukan pada tahun 2003 dan pengukuran ulangan serta pemeliharaan dilakukan pada tahun 2004 dan 2006.

\section{B. Tahapan Penelitian}

Tata cara pembuatan PUP mengacu pada tatacara pemilihan dan pembuatan PUP yang disusun oleh Harbagung dan Djoko Wahyono (1994). Jumlah PUP yang dibuat adalah satu seri PUP per lokasi yang terdiri dari tiga PUP, dan tiap PUP terbagi lagi menjadi 25 petak ukur. Untuk tegakan cendana hanya di buat satu PUP, karena sebaran dan potensi cendana masing-masing seluas \pm 5 ha adalah homogen. Pengamatan dan pengukuran per individu pohon dilakukan secara konsisten. Untuk menjaga konsistensi pengukuran, pohon/tanaman yang ada pada tiap petak ukur $(10 \times 10 \mathrm{~m})$ diberi nomor dan dipetakan dalam tally sheet sehingga memudahkan pada pengukuran berikutnya.

\section{Pembuatan Petak Ukur Pemanen}

Pada areal yang dipilih sebagai lokasi PUP dilakukan pembuatan PUP dengan urutan sebagai berikut :

1) Tumbuhan bawah di areal yang dicadangkan untuk pembuatan PUP dibabad (dibersihkan).

2) PUP dibuat berbentuk segiempat dengan ukuran jarak datar $70 \times 70 \mathrm{~m}$.

3) Di tengah setiap PUP dibuat petak pengamatan berukuran $50 \times 50 \mathrm{~m}$, dan terbagai menjadi plotplot $10 \times 10$ m sebanyak 25 petak ukur (Gambar 1).

4) Semua pohon yang berada di dalam plot setiap petak pengamatan dipolet dengan cat berwarna kuning sebagai tanda pengukuran keliling batang pohon setinggi dada (dbh) atau $\pm 1,30$ meter.

5) Semua pohon yang berada di dalam plot diberi nomor. Penomoran dilakukan secara berurutan dimulai dari pohon-pohon yang terletak pada plot ke-1 kemudian diakhiri pada plot ke-25. Nomor pohon diletakkan di atas polet (warna kuning) dengan cat warna merah menghadap ke arah jalan (agar mudah dilihat). 


\begin{tabular}{|c|c|c|c|c|}
\hline 1 & 2 & 3 & 4 & 5 \\
\hline 10 & 9 & 8 & 7 & 6 \\
\hline 11 & 12 & 13 & 14 & 15 \\
\hline 20 & 19 & 18 & 17 & 16 \\
\hline 21 & 22 & 23 & 24 & 25 \\
\hline
\end{tabular}

\begin{tabular}{|c|c|c|c|c|}
\hline 1 & 2 & 3 & 4 & 5 \\
\hline 10 & 9 & 8 & 7 & 6 \\
\hline 11 & 12 & 13 & 14 & 15 \\
\hline 20 & 19 & 18 & 17 & 16 \\
\hline 21 & 22 & 23 & 24 & 25 \\
\hline
\end{tabular}

\begin{tabular}{|c|c|c|c|c|}
\hline 1 & 2 & 3 & 4 & 5 \\
\hline 10 & 9 & 8 & 7 & 6 \\
\hline 11 & 12 & 13 & 14 & 15 \\
\hline 20 & 19 & 18 & 17 & 16 \\
\hline 21 & 22 & 23 & 24 & 25 \\
\hline
\end{tabular}

Gambar (Figure) 1. Petak Ukur Permanen (Seri PUP) (permanent experimental plot)

\section{Bahan dan Alat}

Bahan dan alat yang dipergunakan dalam penelitian ini adalah :

- Tegakan jati dan cendana

- Kompas, penunjuk arah

- Pitameter, pengukur diameter pohon

- Galah, alat pengukur tinggi

- Hagameter, alat pengukur tinggi pohon

- Rollmeter, pengukur panjang materi dan jarak datar

- Tali plastik $100 \mathrm{~m}$, untuk batas PUP

- Tali rafia, untuk pembuatan plot-plot di dalam PUP

- Kamera, untuk dokumentasi

- Tallysheet, untuk pencatatan data

- Perlengkapan $\mathrm{P}_{3} \mathrm{~K}$

- Parang dan sabit, pembersihan lokasi

\section{E. Analisis Data}

Setelah dilakukan beberapa kali pengukuran ulang dilakukan perhitungan riap. Riap dipakai untuk menyatakan pertambahan dimensi diameter, tinggi pohon, dan volume pohon atau tegakan per satuan luas pada waktu tertentu (tahun). Untuk analisis data ini, dipergunakan dua macam pendekatan perhitungan riap, yaitu riap rata-rata tahunan, MAI (Mean Annual Increment), dan riap ratarata berjalan, CAI (Current Annual Increment). Berikut ini adalah rumus yang dipakai dalam perhitungan riap tegakan :

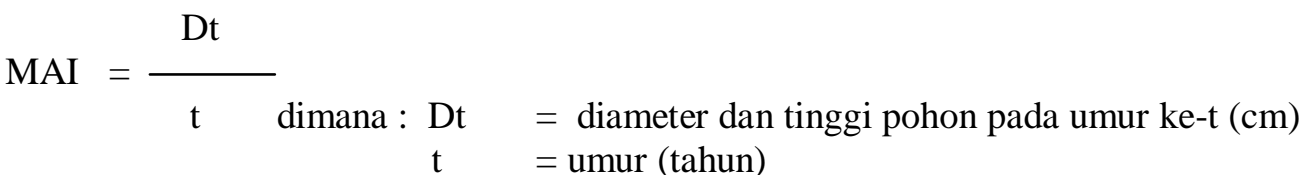

$$
\begin{aligned}
& D_{t}-D_{t-1} \\
& \mathrm{CAI}= \\
& \mathrm{T} \text { dimana: } \mathrm{D}_{\mathrm{t}} \quad=\text { diameter dan tinggi pohon saat pengamatan }(\mathrm{cm}) \\
& \mathrm{D}_{\mathrm{t}-1} \quad=\text { diameter dan tinggi pohon sebelumnya }(\mathrm{cm}) \\
& \mathrm{T}=\text { jarak waktu pengukuran (bulan) }
\end{aligned}
$$




\section{HASIL DAN PEMBAHASAN}

\section{A. Riap Pertumbuhan Tegakan}

\section{Tegakan Jati}

Pada Tabel 1 dapat dilihat bahwa trend perkembangan riap rata-rata tahunan (MAI) jati di Takari baik diameter maupun tinggi tegakan selama empat tahun berbeda dalam penampilan. Pada umumnya MAI diameter cenderung menurun dari umur tegakan 6 tahun sampai 9 tahun, yang diindikasikan oleh nilai MAI-nya selalu lebih tinggi dari pada riap rata-rata tahun berjalan (CAI) diameter. Sedangkan MAI tinggi tegakan cenderung meningkat sampai umur tegakan 10 tahun dengan indikasi nilai MAI lebih rendah dari pada CAI tingginya. Untuk lebih jelasnya, trend perkembangan riap dan perbandingan nilai MAI dan CAI dapat dilihat pada Gambar 2. Namun perkembangan tegakan setelah umur tegakan 10 tahun kemungkinan cenderung meningkat karena pada pengamatan terakhir atau kelima, baik diameter maupun tinggi tegakan cenderung meningkat dengan indikasi masingmasing nilai CAI lebih besar dari pada MAI-nya.

Tabel (Table) 1. Riap rata-rata tahunan (MAI) dan tahun berjalan (CAI) tegakan jati (Mean and current annual increment of $\mathrm{T}$. grandis stand at Takari, Kupang)

\begin{tabular}{|c|c|c|c|c|}
\hline \multirow{2}{*}{$\begin{array}{c}\text { MAI dan CAI (mean and } \\
\text { current annual increment) }\end{array}$} & \multicolumn{3}{|c|}{$\begin{array}{c}\text { Petak Ukur Permanen } \\
\text { (permanent experimental plot) }\end{array}$} & $\begin{array}{c}\text { Rataan } \\
\text { (average) }\end{array}$ \\
\cline { 1 - 4 } Diameter (cm) & 1 & 2 & 3 & 1.5 \\
\hline MAI 1 & 1.5 & 1.4 & 1.8 & 1.5 \\
MAI 2 & 1.5 & 1.3 & 1.6 & 1.4 \\
MAI 3 & 1.3 & 1.3 & 1.5 & 1.3 \\
MAI 4 & 1.3 & 1.2 & 1.4 & 1.4 \\
MAI 5 & 1.4 & 1.3 & 1.4 & 1.2 \\
CAI 1 & 1.7 & 1.1 & 0.8 & 0.5 \\
CAI 2 & 0.1 & 0.9 & 0.6 & 0.7 \\
CAI 3 & 0.6 & 0.9 & 0.6 & 1.8 \\
CAI 4 & 2.4 & 1.6 & 1.6 & 1.2 \\
Tinggi / height (m) & & & & 1.2 \\
MAI 1 & 1.2 & 1.0 & 1.3 & 1.3 \\
MAI 2 & 1.2 & 1.1 & 1.4 & 1.3 \\
MAI 3 & 1.3 & 1.1 & 1.4 & 1.5 \\
MAI 4 & 1.2 & 1.2 & 1.4 & 1.7 \\
MAI 5 & 1.5 & 1.5 & 1.6 & 1.3 \\
CAI 1 & 1.7 & 1.4 & 2.1 & 1.5 \\
CAI 2 & 1.3 & 1.5 & 1.3 & 3.7 \\
CAI 3 & 1.1 & 1.9 & 1.4 & \\
CAI 4 & 4.0 & 3.6 & 3.4 & \\
& & & & \\
\hline
\end{tabular}

Keterangan(remarks) :

MAI 1.2.3. 4 dan $5=$ MAI umur tegakan 6.7.8.9 dan 10 tahun (MAI of stand age in 6.7.8.9 and 10 years)

CAI 1. 2.3 dan $4=$ CAI antara umur 6 dan 7.7 dan 8.8 dan 9. dan 9 dan 10 tahun (CAI of age between 6 and 7.7 and 8.8 and 9 . and 9 and 10 years) 

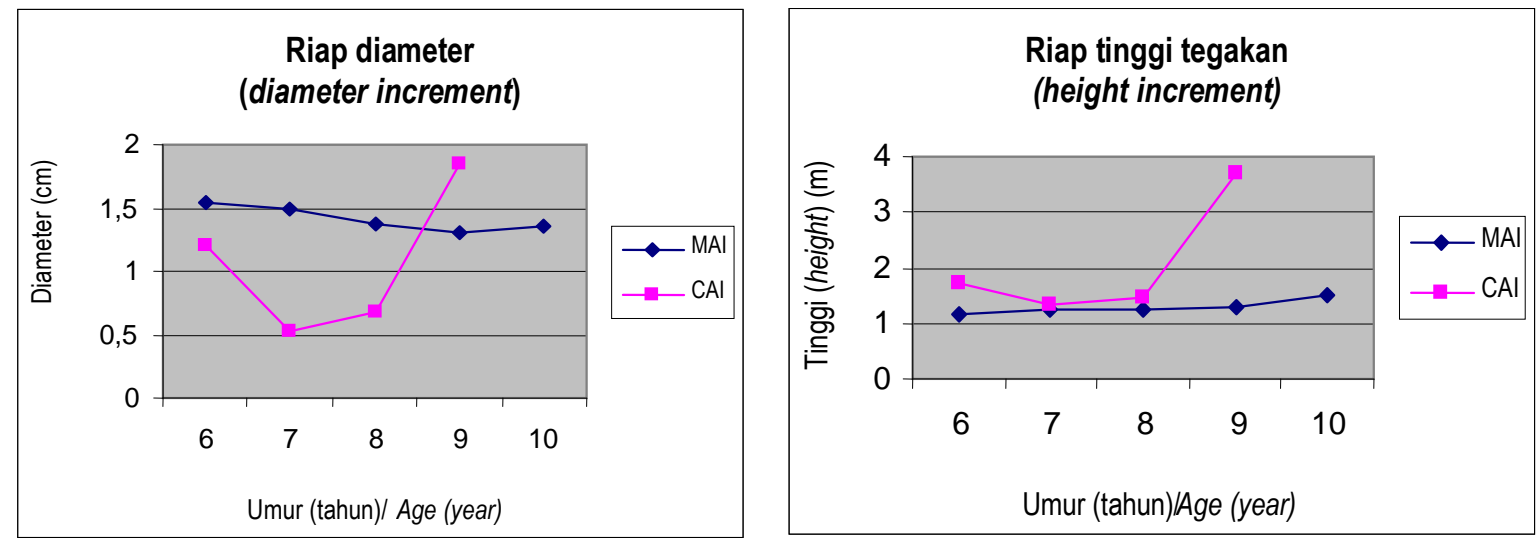

Gambar (Figure) 2. Grafik perkembangan riap tahunan diameter dan tinggi tegakan jati di Takari (trend of MAI on $\mathrm{T}$. grandis stand at Takari)

Fluktuasi perkembangan riap tegakan dalam empat tahun terakhir kemungkinan disebabkan oleh faktor eksternal, yaitu adanya gangguan penggembalaan liar dan pencurian kayu untuk alat-alat rumah tangga dan kayu bakar oleh masyarakat sekitar kawasan hutan. Faktor lain menunjukkan bahwa tegakan jati masih cukup lama menyesuaikan diri pada kondisi tapaknya yang menyebabkan pertumbuhan tegakan tidak berjalan semestinya. Alrasjid (1991) mengemukakan bahwa faktor kualitas lahan yang berperan dalam mempengaruhi pertumbuhan tanaman adalah adalah kandungan humus, kandungan unsur nitrogen, altitude, drainase tanah, solum tanah, curah hujan, jumlah musim (hujankemarau) per tahun dan faktor tekstur tanah.

Pada Tabel 2 dapat dilihat bahwa trend perkembangan riap rata-rata tahunan jati di Polen tahun 1996 baik diameter maupun tinggi tegakan selama dua tahun sampai umur tegakan delapan tahun relatif sama, yaitu terjadi penurunan riap rata-rata tahunan (MAI) dari umur tegakan 6 tahun sampai umur 8 tahun dengan fluktuasi perubahan turun-naik selama 2 tahun. Untuk lebih jelasnya trend perkembangan riap tegakan jati 1996 dapat dilihat pada Gambar 3.

Tabel (Table) 2. Riap rata-rata tahunan (MAI) dan tahun berjalan (CAI) tegakan jati tahun 1996 di Polen (mean and current annual increment of Tectona grandis stand 1996 at Polen)

\begin{tabular}{|c|c|c|c|c|}
\hline $\begin{array}{c}\text { MAI dan CAI (mean and } \\
\text { current annual increment) }\end{array}$ & \multicolumn{3}{|c|}{$\begin{array}{c}\text { Petak Ukur Permanen } \\
\text { (permanent experimental plot) }\end{array}$} & $\begin{array}{c}\text { Rataan } \\
\text { (average) }\end{array}$ \\
\cline { 1 - 3 } Diameter (cm) & 1 & 2 & 3 & 1.1 \\
MAI 1 & 1.3 & 1.0 & - & 1.0 \\
MAI 2 & 1.3 & 1.1 & 0.8 & 1.0 \\
MAI 3 & 1.2 & 1.0 & 0.8 & 1.5 \\
CAI 1 & 1.2 & 1.7 & - & 0.9 \\
CAI 2 & 0.8 & 1.0 & 1.0 & 0.9 \\
Tinggi / height (m) & 1.0 & 0.8 & - & 0.7 \\
MAI 1 & 0.9 & 0.7 & 0.6 & 0.8 \\
MAI 2 & 0.9 & 0.7 & 0.7 & 0.2 \\
MAI 3 & 0.2 & 0.3 & - & 1.0 \\
\hline CAI 1 & 1.2 & 0.7 & 0.9 & \\
\hline
\end{tabular}

Keterangan(remarks) :

MAI 1.2.3 = MAI umur tegakan 6. 7. dan 8 tahun (MAI of stand age in 6.7 and 8 years)

CAI 1.2 = CAI antara umur 6 dan 7. dan 7 dan 8 (CAI of age between 6 and 7, and 7 and 8 years) 

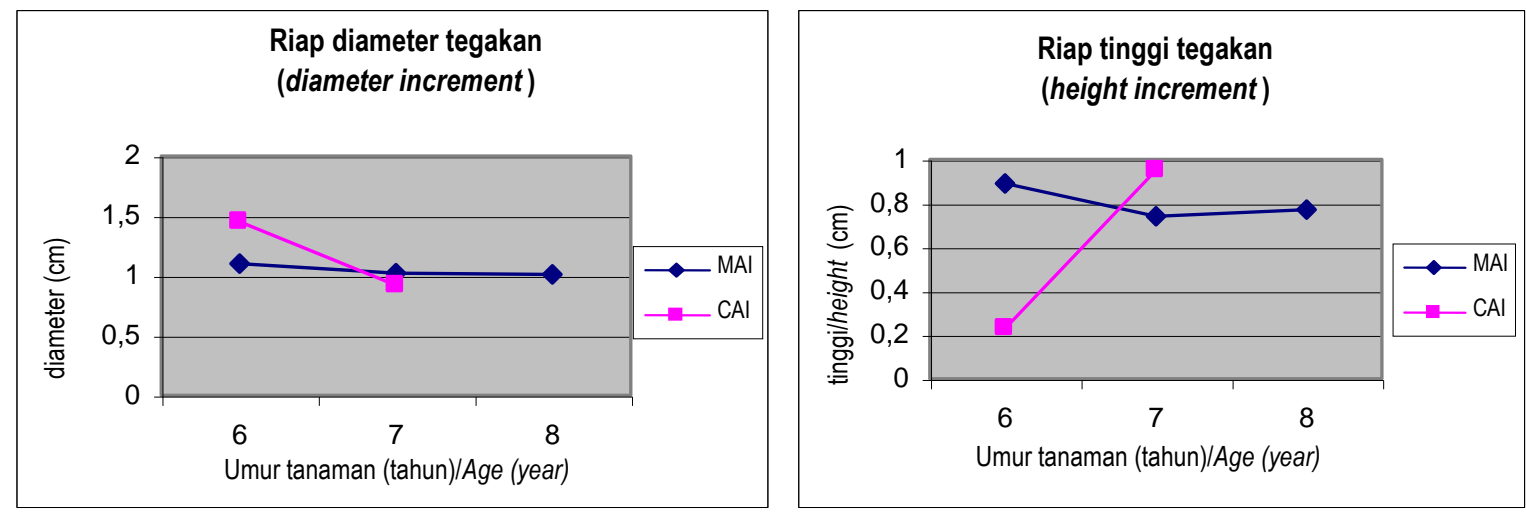

Gambar (Figure) 3. Grafik perkembangan riap tahunan diameter dan tinggi tegakan jati di Polen 1996 (trend of MAI on T. grandis stand in 1996 at Takari)

Pada Tabel 3 dan Gambar 4 dapat dilihat bahwa trend perkembangan riap rata-rata tahunan tegakan jati di Polen tahun 1997 agak berbeda antara diameter dan maupun tinggi tegakan. MAIdiameter terjadi peningkatan selama dua tahun dari umur tegakan 5 tahun sampai umur 7 tahun sedangkan MAI-tinggi relatif sama dengan perkembangan tegakan jati 1996, yaitu terjadi penurunan dengan fluktuasi perubahan turun-naik selama 2 tahun.

Rendahnya perkembangan riap tegakan dalam dua tahun terakhir kemungkinan kasusnya relatif sama dengan tegakan tanaman jati tahun 1996, yaitu karena pengaruh gangguan ternak dan tapak tegakan yang kurang mendukung pertumbuhan tegakan optimal.

Tabel (Table) 3. Riap rata-rata tahunan (MAI) dan tahun berjalan (CAI) tegakan jati tahun 1997 di Polen (mean and current annual increment of T. grandis stand 1997 at Polen)

\begin{tabular}{|c|c|c|c|c|}
\hline $\begin{array}{c}\text { MAI dan CAI (mean and } \\
\text { current annual increment) }\end{array}$ & \multicolumn{3}{|c|}{$\begin{array}{c}\text { Petak Ukur Permanen } \\
\text { (permanent experimental plot) }\end{array}$} & $\begin{array}{c}\text { Rataan } \\
\text { (average) }\end{array}$ \\
\cline { 1 - 3 } Diameter (cm) & 1 & 2 & 3 & 1.2 \\
MAI 1 & 1.2 & 1.2 & 1.1 & 1.2 \\
MAI 2 & 1.3 & 1.2 & 1.0 & 1.2 \\
MAI 3 & 1.2 & 1.3 & 1.2 & 1.0 \\
CAI 1 & 1.4 & 0.8 & 0.8 & 1.9 \\
CAI 2 & 1.1 & 2.3 & 2.0 & \\
Tinggi / height (m) & & & & 1.0 \\
MAI 1 & 1.0 & 1.1 & 1.0 & 0.9 \\
MAI 2 & 0.9 & 1.0 & 0.8 & 1.0 \\
MAI 3 & 1.1 & 1.0 & 0.9 & 0.3 \\
CAI 1 & 0.1 & 0.3 & 0.1 & 1.6 \\
CAI 2 & 1.8 & 1.5 & 1.5 & \\
\hline
\end{tabular}

Keterangan(remarks) :

MAI 1.2.3 = MAI umur tegakan 5. 6. dan 7 tahun (MAI of stand age in 5.6 and 7 years)

CAI $1.2=$ CAI antara umur 5 dan 6. dan 6 dan 7 (CAI of age between 5 and 6. and 6 and 7 years)

Sampai umur tegakan 7 tahun, penampilan tegakan jati 1997 adalah diameter $8,70 \mathrm{~cm}$; tinggi pohon 7,02 m; riap tahunan diameter $1,24 \mathrm{~cm}$ dan riap tahunan tinggi tegakan adalah 1,00 m. Dari data ini terlihat bahwa penampilan tegakan jati tahun 1997 relatif lebih baik dan lebih produktif dari pada tegakan jati tahun 1996. Secara fenotif, kualitas tapak tegakan tahun 1996 relatif lebih jelek, 
yaitu pada waktu musim hujan tanahnya lebih becek dan lengket, dan pada waktu musim kemarau tanahnya pecah-pecah.
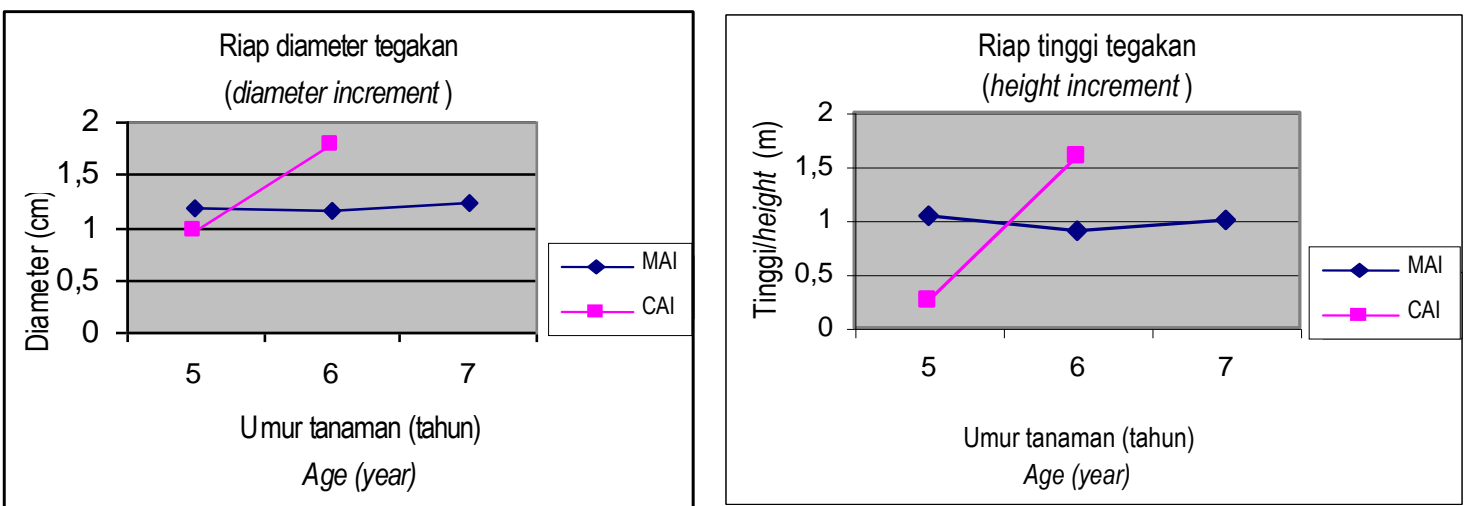

Gambar (Figure) 4. Grafik perkembangan riap tahunan diameter dan tinggi tegakan jati di Polen 1997 (trend of MAI on T. grandis stand in 1997 at Polen)

Rata-rata jumlah pohon di dalam PUP di Takari adalah 184 pohon (ukuran 50 x $50 \mathrm{~m}$ ) dan dalam 1 ha terdapat 736 pohon. Dengan asumsi nilai angka bentuk jati $F=0,76$ (Susila, 2004) maka riap volume tahunan rata-rata per ha tegakan (etat) jati sampai umur 10 tahun adalah $7,67 \mathrm{~m}^{3}$ (Tabel 4). Pada tegakan jati di Polen tahun tanam 1996, dimana rata-rata jumlah pohon adalah 200 pohon dan dalam satu hektar terdapat 800 pohon, maka riap volume tahunan rata-rata per hektar sampai umur 8 tahun adalah $1,96 \mathrm{~m}^{3}$. Sedangkan pada tegakan jati tahun tanam 1997, rata-rata jumlah pohon di dalam PUP adalah 201 pohon dan dalam satu hektar terdapat 804 pohon, maka riap rata-rata volume tahunan per hektar sampai umur 7 tahun adalah 2,27 $\mathrm{m}^{3}$ (Tabel 4).

Tabel (Table) 4. Potensi tegakan jati di Takari Kupang dan Polen Timor Tengah Selatan (potential of T. grandis stand at Takari and Polen)

\begin{tabular}{|l|c|c|c|c|c|}
\hline $\begin{array}{c}\text { Tegakan jati } \\
\text { (stand of jati) }\end{array}$ & $\begin{array}{c}\text { Jumlah pohon } \\
\text { (number of tree }) \\
\text { per ha }\end{array}$ & $\begin{array}{c}\mathrm{D} \\
(\mathrm{cm})\end{array}$ & $\begin{array}{c}\mathrm{T} \\
(\mathrm{m})\end{array}$ & $\begin{array}{c}\mathrm{V} \\
\left(\mathrm{m}^{3} / \mathrm{ha}\right)\end{array}$ & $\begin{array}{c}\mathrm{MAI}-\mathrm{V} \\
\left(\mathrm{m}^{3} / \mathrm{ha} / \mathrm{th}\right)\end{array}$ \\
\hline Tegakan Takari umur 10 tahun & 736 pohon & 13.5 & 15.2 & 76.71 & 7.67 \\
\hline Tegakan Polen: & 800 pohon & 9.0 & 6.5 & 15.70 & 1.96 \\
- Tahun 1996: umur 8 tahun & 804 pohon & 8.7 & 7.0 & 15.91 & 2.27 \\
- Tahun 1997: umur 7 tahun & & & & & \\
\hline
\end{tabular}

Keterangan (Remarks) :

$\mathrm{D}$ dan $\mathrm{T}=$ rerata diameter dan tinggi tegakan (diametre and height mean of stand)

$\mathrm{V}=$ volume tegakan per hektar (volume of stand)

$\mathrm{MAI}-\mathrm{V}=$ riap tahunan rata-rata volume (mean annual increment of volume)

Jika dibandingkan dengan riap tegakan jati di Takari, riap tegakan jati di Polen relatif rendah. Rendahnya perkembangan riap tegakan dalam dua tahun terakhir kemungkinan disebabkan oleh faktor eksternal dan internal. Faktor eksternal yaitu adanya gangguan penggembalaan liar dan pencurian kayu untuk pemanfaatan alat-alat rumah tangga dan kayu bakar oleh masyarakat sekitar kawasan hutan, yang diindikasikan oleh banyaknya kotoran sapi dan bekas potongan ranting batang pohon di lokasi penelitian. Pengaruh faktor internal yaitu tapak tegakan kemungkinan kurang mendukung pertumbuhan 
tegakan yang optimal dimana tanah tegakan terlihat pecah-pecah pada waktu musim kemarau dan agak becek pada waktu musim hujan. Pengaruh kompetisi antar individu pohon di dalam tegakan dalam hal pemanfaatan sinar matahari kemungkinan belum terjadi karena ruang tumbuh masih relatif luas (pertajukan belum bersentuhan pada waktu musim hujan) sehingga sinar matahari leluasa masuk sampai lantai bawah tegakan.

\section{Tegakan Cendana}

Tabel (Table) 5. Riap tegakan cendana di Kawasan Hutan Omtel, Kab. Alor (stand increment of sandalwood at forest group of Omtel, Alor District)

\begin{tabular}{|c|c|c|}
\hline Parameter & $\begin{array}{c}\text { Tegakan tahun } \\
\text { (stand of year) } 1976\end{array}$ & $\begin{array}{c}\text { Tegakan tahun } \\
\text { (stand of year) 1987 }\end{array}$ \\
\hline Diameter (cm) : & 0,4 & 0,7 \\
MAI-1 & 0,4 & 0,6 \\
MAI-2 & 0,4 & 0,6 \\
MAI-3 & 11,2 & 10,4 \\
D1 & 11,4 & 10,6 \\
D2 & 11,9 & 11,1 \\
D3 & 0,1 & 0,2 \\
CAI-1 & 0,3 & 0,2 \\
CAI-2 & & \\
MAI-1 & 0,2 & 0,4 \\
MAI-2 & 0,2 & 0,4 \\
MAI-3 & 0,2 & 0,3 \\
T1 & 5,4 & 5,7 \\
T2 & 5,8 & 6,0 \\
T3 & 6,1 & 6,3 \\
CAI-1 & 0,4 & 0,3 \\
CAI-2 & 0,1 & 0,2 \\
\hline Tinggi/heigh (m)
\end{tabular}

Keterangan (Remarks) :

MAI-1,2,3 = riap rata-rata tahunan pada pengukuran ke 1, 2, dan 3 (mean annual increment on measurement year 1 st, 2 nd and $3 \mathrm{rd}$ )

$\mathrm{D}$ dan $\mathrm{T} 1,2,3$ = diameter dan tinggi rata-rata pada pengukuran ke 1, 2 dan 3 (mean diametre and height on measurement year 1 st, 2 nd and $3 \mathrm{rd}$ )

$\mathrm{CAI}-1,2=$ riap rata-rata tahun berjalan ke 1 dan 2 (current annual increment between of measurement year 1 st and 2 nd, 2 nd and $3 \mathrm{rd}$ )

Pada Tabel 5 disajikan riap tegakan cendana tahun 1975, yaitu MAI diameter dan tinggi tegakan dua tahun terakhir yang mengalami penurunan. Trend perkembangan riap tahunan dapat diperjelas seperti pada Gambar 5, yaitu riap tahunan diameter menurun secara perlahan karena nilainya selalu di atas (lebih besar) dari riap tahunan berjalan (CAI), walaupun CAI cenderung selalu meningkat. MAI tinggi cenderung meningkat pada awal pengukuran, kemudian menurun secara perlahan karena pada awalnya nilai CAI lebih besar (di atas) dan kemudian pengukuran terakhir lebih kecil (di bawah) nilai MAI nya.

Untuk tegakan cendana tahun tanam 1987, riap tahunan tegakan mengalami penurunan baik untuk MAI diameter maupun untuk tinggi pohon. Indikasi penurunan riap tegakan ini, disamping dapat dilihat dari data MAI tiga tahun berturut-turut, juga dapat dilihat dari nilai riap tahunan berjalan tegakan (CAI) yaitu nilai CAI untuk setiap parameter yang diukur dan dihitung selalu lebih kecil dari pada nilai MAI-nya (Gambar 3). 

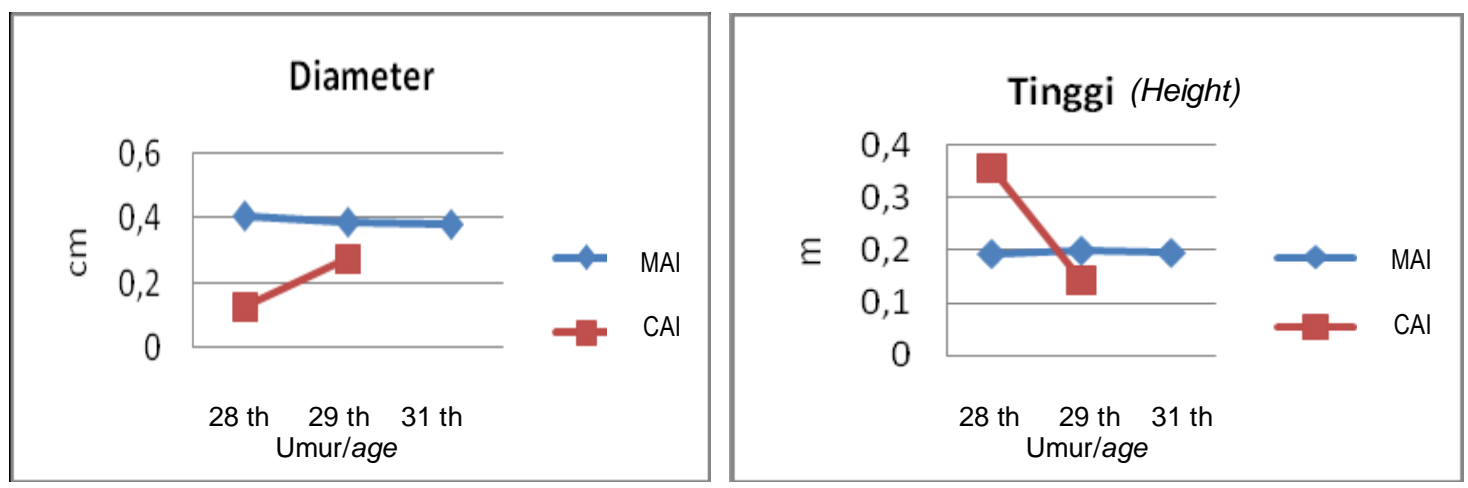

Gambar (Figure) 5. Grafik perkembangan riap tahunan diameter dan tinggi tegakan cendana tahun 1976 (trend of MAI on sandalwood stand in 1976)
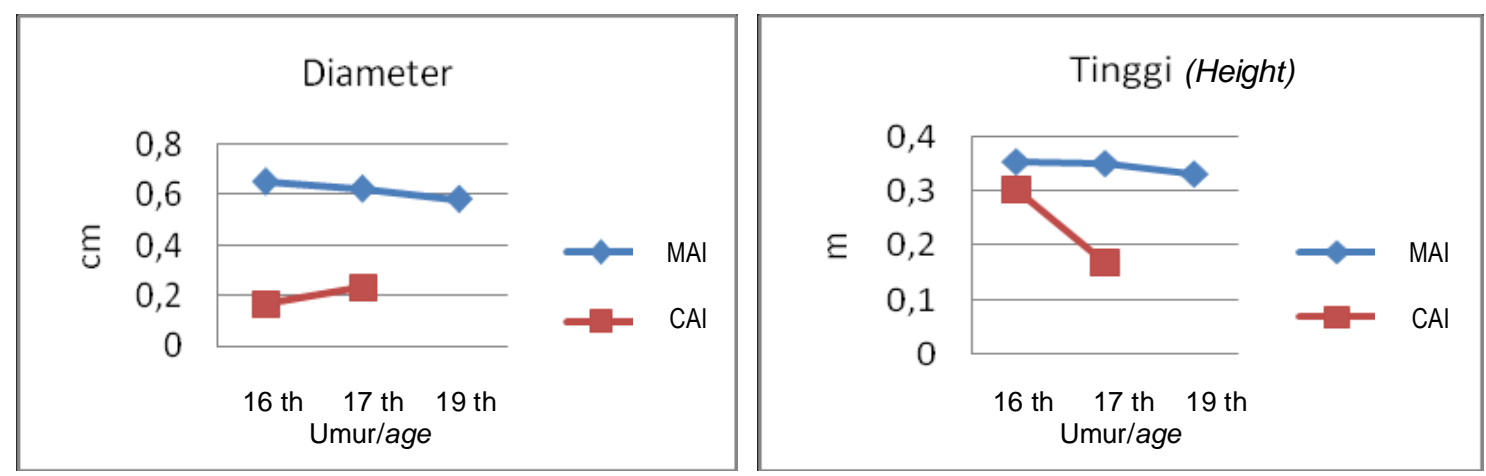

Gambar (Figure) 6. Grafik perkembangan riap tahunan diameter dan tinggi tegakan cendana tahun 1987 (trend of MAI on sandalwood stand in 1987)

Menurunnya MAI tegakan cendana tersebut di atas disebabkan oleh kondisi tapak yang kurang mendukung untuk pertumbuhan tegakan yang optimal. Kemungkinan telah terjadi kompetisi antar individu pohon dalam pemanfaatan ruang tumbuh, baik terhadap pemanfaatan sinar matahari maupun terhadap unsur hara di dalam tanah yang mempengaruhi pertumbuhan tegakan. Kondisi tempat tumbuh tegakan pada umumnya banyak ditumbuhi oleh semak belukar yang relatif cukup rapat. Untuk tegakan cendana 1976, kondisi semak belukar relatif lebih rapat dari pada tegakan cendana 1987. Faktor kualitas lahan yang berperan dalam mempengaruhi pertumbuhan tanaman adalah kandungan humus, kandungan unsur nitrogen, altitude, drainase tanah, solum tanah, curah hujan, jumlah musim (hujankemarau) per tahun dan faktor tekstur tanah (Alrasjid,1991). Sejauh ini belum sempat dilakukan pengamatan sifat biofisik lahan/tapak tegakan cendana, namun secara fenotif terutama pada tegakan 1976, pada waktu musim kemarau kondisi tanah tegakan agak pecah-pecah secara sporadis dan berlumpur pada waktu musim hujan. Sampai saat ini belum pernah dilakukan penjarangan dan pemeliharaan tegakan untuk meminimalkan gangguan gulma (semak belukar). Tegakan cendana ini merupakan tegakan hasil reboisasi yang pada umumnya menerima perlakuan pemeliharaan sampai umur tanaman 3 tahun. Penyebab lain menurunnya riap tegakan adalah adanya gangguan masyarakat terhadap beberapa pohon cendana dengan menakik dan melubangi batang dan cabang pohon cendana.

Dalam kondisi tapak yang optimal (menguntungkan), pertumbuhan pohon cendana akan semakin meningkat setiap tahun. Hasil penelitian yang dilakukan oleh Warsito dan Andayani (1987) menunjukkan bahwa pada umur 45 tahun pohon cendana masih belum mencapai riap tahunan berjalan (CAI) dan riap tahunan rata-rata (MAI) tertinggi. Oleh karena itu diperlukan perhatian dari pihak pengelola dalam hal ini Dinas Kehutanan dan Perkebunan Kabupaten Alor untuk meningkatkan 
pembinaan dan pengelolaan terhadap tegakan tersebut sehingga riap tegakan dapat meningkat setiap tahun.

Pada tegakan cendana tahun 1976, jumlah pohon di dalam PUP adalah 53 pohon (ukuran $50 \mathrm{x}$ $50 \mathrm{~m}$ ) dan dalam 1 ha terdapat 212 pohon, dengan asumsi nilai angka bentuk cendana $\mathrm{F}=0,7$; maka riap volume rata-rata tahunan (etat) tegakan cendana sampai umur 28 tahun adalah $0,29 \mathrm{~m}^{3} \mathrm{ha}^{-1} \mathrm{th}^{-1}$ dan sampai umur 31 tahun etat tegakan mengalami peningkatan yaitu $0,32 \mathrm{~m}^{3} \mathrm{ha}^{-1} \mathrm{th}^{-1}$ (Tabel 6), sedangkan untuk tegakan tahun 1987, jumlah pohon di dalam PUP adalah 83 pohon dan dalam 1 ha terdapat 332 pohon, maka etat tegakan cendana sampai umur 16 tahun adalah $0,70 \mathrm{~m}^{3} \mathrm{ha}^{-1} \mathrm{th}^{-1}$ dan sampai umur 19 tahun adalah $0,74 \mathrm{~m}^{3} \mathrm{ha}^{-1} \mathrm{th}^{-1}$ (Tabel 6).

Tabel (Table) 6. Potensi tegakan cendana di Alor Barat Laut, Kabupaten Alor (potency of sandalwood stand at Alor Barat Laut, Alor District)

\begin{tabular}{|l|c|c|c|c|c|}
\hline \multicolumn{1}{|c|}{$\begin{array}{c}\text { Tegakan cendana } \\
\text { (stand of cendana })\end{array}$} & $\begin{array}{c}\text { Jumlah pohon } \\
(\text { number of tree }) \\
\text { per ha }\end{array}$ & $\begin{array}{c}\mathrm{D} \\
(\mathrm{cm})\end{array}$ & $\begin{array}{c}\mathrm{T} \\
(\mathrm{m})\end{array}$ & $\begin{array}{c}\mathrm{V} \\
\left(\mathrm{m}^{3} / \mathrm{ha}\right)\end{array}$ & $\begin{array}{c}\mathrm{MAI}-\mathrm{V} \\
\left(\mathrm{m}^{3} / \mathrm{ha} / \mathrm{th}\right)\end{array}$ \\
\hline Tahun 1975: & 212 pohon & 11,2 & 5,4 & 8,0 & 0,29 \\
umur 28 tahun & 212 pohon & 11,9 & 6,1 & 10,0 & 0,32 \\
umur 31 tahun & 332 pohon & 10,4 & 5,7 & 11,2 & 0,70 \\
\hline Tahun 1987: & 332 pohon & 11,1 & 6,3 & 14,1 & 0,74 \\
umur 16 tahun & & & & & \\
umur 19 tahun & & & & & \\
\hline
\end{tabular}

Keterangan (Remarks) :

$\mathrm{D}$ dan $\mathrm{T}=$ diameter dan tinggi tegakan (diameter and height of stand)

$\mathrm{V}=$ volume tegakan (volume of stand)

MAI-V = riap tahunan rata-rata volume (mean annual increment of volume)

Dari hasil etat kedua tegakan cendana tersebut dapat dinyatakan bahwa cendana memang termasuk jenis yang riapnya relatif lambat. Kalau dibandingkan dengan riap hutan alam primer (relatif banyak kompetisi antar individu pohon) yang diasumsikan etatnya kurang lebih $1 \mathrm{~m}^{3} \mathrm{ha}^{-1} \mathrm{th}^{-1}$, maka etat cendana ini masih lebih kecil. Oleh karena itu, riap tegakan cendana tersebut masih bisa ditingkatkan produksinya sampai melebihi etat hutan alam dengan memperbaiki sistem pengelolaannya. Rai dan Kulkarni (1986) dalam Barret (1989) menyatakan bahwa cendana tumbuh sangat lambat, dengan riap diameter batang sebesar $1 \mathrm{~cm}$ tahun $^{-1}$. namun pada kondisi tanah dan lembab nisbi yang menguntungkan akan dicapai riap $5 \mathrm{~cm}$ tahun $^{-1}$.

\section{B. Prediksi Pertumbuhan Parameter Tegakan}

Prediksi pertumbuhan parameter tegakan dapat didekati melalui model-model persamaan dengan menggunakan faktor umur tanaman. Data pengamatan yang telah ada adalah data diameter, tinggi, umur dan parameter lainnya dari beberapa kali pengukuran sesuai umur tegakan. Sedangkan umur setelah itu, parameter dapat ditentukan melalui model persamaan regresi yang telah disusun. Ada empat model persamaan regresi yang dicobakan dari indikasi parameter-parameter tersebut yaitu regresi linear, logaritma, kuadratik dan eksponen. Model-model regresi terbaik dipilih berdasarkan tingkat ketelitian/ketepatan, tingkat signifikansi dan kesederhanaan model. 


\section{Model pertumbuhan tegakan jati}

Pada Tabel 7 disajikan model-model terpilih menurut parameter tak bebas pada tegakan jati di Takari. Pada tabel tersebut terlihat bahwa hanya model persamaan nomor 3 dan 4 yang mempunyai galat baku (Se) lebih dari $25 \%$ yang melebihi besaran sesuai persyaratan yang diperkenankan, sedangkan model persamaan yang lainnya cukup teruji keterhandalannya, karena mempunyai tingkat kesalahan yang rendah (di bawah $10 \%$ ) dan peubah bebas atau faktor umur sangat berpengaruh terhadap pendugaan parameter sampai taraf nyata di atas $95 \%$. Keterhandalan model dapat dicirikan dengan nilai $\mathrm{R}^{2}$ yang tinggi (sangat signifikan) dan Se yang rendah. Menurut Marcelino (1960) dan Prodan (1965) dalam Bustomi dan Sumarna (1986), dalam menyusun suatu model berdasarkan persamaan regresi yang menggunakan satu peubah diperkenankan galat baku $25 \%$, sedangkan apabila menggunakan dua peubah diperkenankan galat baku $20 \%$.

Tabel (Table) 7. Model-model regresi terpilih beberapa parameter pada tegakan jati di Takari (selected regression models of parametres of $\mathrm{T}$. grandis stand at Takari)

\begin{tabular}{|c|l|c|c|c|}
\hline No & \multicolumn{1}{|c|}{ Model Regresi (regression models) } & $\mathrm{R}^{2}(\%)$ & Se $(\%)$ & Sign $\mathrm{F}$ \\
\hline 1 & MAI-t $(\mathrm{m})=0,81412+0,05725^{\mathrm{X}}$ & 47,36 & 9,17 & 0,01 \\
2 & MAI-d $(\mathrm{cm})=1,94257-0,04020^{\mathrm{X}}$ & 36,24 & 8,10 & 0,02 \\
3 & CAI-t $(\mathrm{m})=33,15212-9,10498 \mathrm{X}+0,64685 \mathrm{X}^{2}$ & 89,78 & 36,24 & 0,00 \\
4 & CAI-d $(\mathrm{cm})=24,88534-6,71674 \mathrm{X}+0,46177 \mathrm{X}^{2}$ & 71,91 & 37,38 & 0,03 \\
5 & T $(\mathrm{m})=2,31488+0,18455^{\mathrm{X}}$ & 90,90 & 8,87 & 0,00 \\
6 & D $(\mathrm{cm})=5,52356+0,08710^{\mathrm{X}}$, & 73,88 & 7,87 & 0,00 \\
\hline
\end{tabular}

Keterangan (Remarks): $\mathrm{X}=$ umur tanaman (age of stand)

Pada Tabel 8 disajikan model-model terpilih menurut parameter tak bebas pada tegakan jati di Polen tahun 1996. Dalam tabel tersebut terlihat bahwa semua model persamaan regresi yang terpilih adalah sah, artinya mempunyai tingkat kesalahandugaan (galat baku) tidak melebihi besaran sesuai persyaratan yang diperkenankan, yaitu $25 \%$. Namun, pada model persamaan nomor 1, 2, 5 dan nomor 6 faktor umur relatif kurang berpengaruh terhadap pendugaan pertumbuhan sampai pada taraf nyata 95 $\%$, hanya berpengaruh sampai kurang dari $30 \%$. Sedangkan model persamaan nomor 3 dan 4 cukup teruji keterhandalannya karena kesalah dugaan yang rendah dan peubah bebasnya sangat nyata pada selang kepercayaan lebih dari $95 \%$.

Tabel (Table) 8. Model-model regresi terpilih beberapa parameter pada tegakan jati 1996 di Polen (selected regression models of parametres T. grandis stand 1996 in Polen)

\begin{tabular}{|c|l|c|c|c|}
\hline No. & \multicolumn{1}{|c|}{ Model Regresi (regression models) } & $\mathrm{R}^{2}(\%)$ & Se $(\%)$ & Sign F \\
\hline 1 & MAI-t $(\mathrm{m})=5,78927-1,28645 \mathrm{X}+0,087600 \mathrm{X}^{2}$ & 26,23 & 12,56 & 0,47 \\
2 & MAI-d $(\mathrm{cm})=1,35274-0,04448 \mathrm{X}$ & 12,53 & 20,90 & 0,66 \\
3 & CAI-t $(\mathrm{m})=-4,09780+0,72073 \mathrm{X}$ & 87,10 & 17,54 & 0,02 \\
4 & CAI-d $(\mathrm{cm})=20,78525-0,44544^{\mathrm{x}}$ & 79,01 & 14,52 & 0,04 \\
5 & T $(\mathrm{m})=3,22056+0,07528^{\mathrm{X}} \mathrm{x}$ & 15,72 & 15,71 & 0,33 \\
6 & D $(\mathrm{cm})=3,60766+0,09730^{\mathrm{X}}$ & 14,57 & 21,24 & 0,35 \\
\hline
\end{tabular}

Model-model persamaan terpilih dari hasil analisa regresi data tegakan jati tahun tanam 1997 disajikan pada Tabel 9. Hanya satu model persamaan yang tidak sah (model nomor 4), artinya mempunyai tingkat kesalahan pendugaan melebihi persyaratan yang diperkenankan. Lima model sah, namun dua model lainnya tidak signifikan sampai taraf nyata $95 \%$ yaitu model nomor 1 dan 2 , sedangkan pada tiga model yang lain (nomor 3, 5 dan 6) faktor umur sangat nyata berpengaruh sampai taraf nyata $99 \%$. 
Tabel (Table) 9. Model-model regresi terpilih beberapa parameter pada tegakan jati 1997 di Polen (selected regression models of parameter T. grandis stand 1997 in Polen)

\begin{tabular}{|c|l|c|c|c|}
\hline No. & \multicolumn{1}{|c|}{ Model Regresi (regression models) } & $\mathrm{R}^{2}(\%)$ & Se $(\%)$ & Sign $\mathrm{F}$ \\
\hline 1 & MAI-t $(\mathrm{m})=5,06150-1,36836 \mathrm{X}+0,11262 \mathrm{X}^{2}$ & 51,74 & 6,49 & 0,11 \\
2 & MAI-d $(\mathrm{cm})=1,03448+0,02348^{\mathrm{X}}$ & 8,09 & 7,33 & 0,46 \\
3 & CAI-t $(\mathrm{m})=-6,43640+1,33747 \mathrm{X}$ & 96,66 & 15,24 & 0,00 \\
4 & CAI-d $(\mathrm{cm})=0,04497+0,60596^{\mathrm{X}}$ & 50,17 & 36,98 & 0,12 \\
5 & T $(\mathrm{m})=2,33788+0,15172^{\mathrm{X}}$ & 73,53 & 8,43 & 0,00 \\
6 & $\mathrm{D}(\mathrm{cm})=2,25149+0,19089^{\mathrm{X}}$ & 86,17 & 7,08 & 0,00 \\
\hline
\end{tabular}

\section{Model Pertumbuhan Tegakan Cendana}

Pada Tabel 10 disajikan model-model terpilih berdasarkan parameter-parameter tak bebas pada tegakan cendana tahun 1976 di Alor. Pada tabel tersebut dapat dilihat bahwa semua model yang dibentuk mempunyai nilai Se yang sesuai dengan yang diperkenankan. Kecuali model nomor 1, semua model mempunyai koefisien determinasi yang relatif tinggi (> $90 \%)$, artinya mempunyai hubungan yang sangat erat antara peubah bebas (faktor umur) dengan peubah tak bebas (parameter lainnya). Hanya kurang dari $10 \%$ faktor lain (faktor non umur tegakan) yang berpengaruh terhadap parameterparameter tersebut. Namun, semua model persamaan regresi yang dibentuk tidak signifikan sampai selang kepercayaan $95 \%$.

Tabel (Table) 10. Model-model regresi terpilih beberapa parameter pada tegakan cendana 1976 di Alor (selected regression models of parametres sandalwood stand at Alor)

\begin{tabular}{|c|l|c|c|c|}
\hline No & \multicolumn{1}{|c|}{ Model Regresi (regression models) } & $\mathrm{R}^{2}(\%)$ & Se $(\%)$ & Sign F \\
\hline 1 & MAI-t $(\mathrm{m})=0,1864+0,0003 \mathrm{X}$ & 3,30 & 0,40 & 0,884 \\
2 & Log MAI-d (cm) = Log 0,9356-0,1609 Log X & 94,28 & 0,29 & 0,154 \\
3 & Log T $(\mathrm{m})=\log -14,6848+6,0541 \log \mathrm{X}$ & 94,24 & 10,94 & 0,154 \\
4 & $\mathrm{D}(\mathrm{cm})=6,5412+0,0192^{\mathrm{X}}$ & 96,24 & 0,82 & 0,124 \\
\hline
\end{tabular}

Keterangan (Remarks): $\mathrm{X}=$ umur tegakan (age of stand)

Model-model persamaan regresi tegakan cendana tahun 1987 disajikan pada Tabel 11. Pada Tabel tersebut dapat dilihat bahwa semua model mempunyai galat baku yang diperkenankan $(<25 \%)$, bahkan tingkat ketelitian model tersebut relatif tinggi. Disamping itu, koefisien determinasi modelmodel tersebut relatif sangat tinggi, artinya ketergantungan nilai parameter peubah tak bebas terhadap faktor umur lebih dari $95 \%$ (hanya kurang dari $5 \%$ karena pengaruh faktor lainnya). Akan tetapi hanya dua model yang dibentuk (model 2 dan 4) cukup signifikan sampai selang kepercayaan $95 \%$.

Tabel (Table) 11. Model-model regresi terpilih beberapa parameter pada tegakan Cendana $1987 \mathrm{di}$ Alor (selected regression models of parameter sandalwood stand at Alor)

\begin{tabular}{|c|l|c|c|c|}
\hline No & \multicolumn{1}{|c|}{ Model Regresi (regression models) } & $\mathrm{R}^{2}(\%)$ & Se $(\%)$ & Sign F \\
\hline 1 & MAI-t $(\mathrm{m})=0,4780-0,0076$ X & 95,76 & 0,35 & 0,132 \\
2 & Log MAI-d (cm) = Log 1,7662-0,4025 Log X & 99,55 & 0,33 & 0,043 \\
3 & Log T $(\mathrm{m})=\log -4,4230+3,6507$ Log X & 98,07 & 6,31 & 0,089 \\
4 & D $(\mathrm{cm})=6,9839+0,2140 \mathrm{X}$ & 99,45 & 3,45 & 0,047 \\
\hline
\end{tabular}




\section{KESIMPULAN}

1. Riap tegakan (MAI) jati di Takari pada umur 10 tahun adalah riap volume $7,67 \mathrm{~m}^{3} \mathrm{ha}^{-1} \operatorname{tahun}^{-1}$, riap rata-rata diameter tegakan $1,4 \mathrm{~cm} \operatorname{tahun}^{-1}$ dan riap rata-rata tinggi tegakan $1,5 \mathrm{~m}$ per tahun. MAI jati di Polen pada umur 8 tahun adalah riap volume $1,96 \mathrm{~m}^{3} \mathrm{ha}^{-1}$ tahun $^{-1}$, riap rata-rata diameter tegakan $1,0 \mathrm{~cm}_{\text {tahun }^{-1}}$ dan riap rata-rata tinggi tegakan $0,8 \mathrm{~m}_{\text {tahun }}{ }^{-1}$. Sedangkan riap jati pada umur 7 tahun adalah riap volume $2,27 \mathrm{~m}^{3} \mathrm{ha}^{-1} \operatorname{tahun}^{-1}$, riap rata-rata diameter tegakan $1,2 \mathrm{~cm}^{-1}$ tahun $^{-1}$ dan riap tinggi tegakan $1,0 \mathrm{~m}_{\text {tahun }}^{-1}$.

2. Riap tegakan cendana di Alor pada umur 31 tahun adalah riap volume tegakan $=0,32 \mathrm{~m}^{3} \mathrm{ha}^{-1}$ tahun $^{-1}$, riap rata-rata diameter $=0,4 \mathrm{~cm} \mathrm{tahun}^{-1}$, dan riap rata-rata tinggi tegakan $=0,2 \mathrm{~m} \mathrm{tahun}^{-1}$. Sedangkan riap tegakan cendana pada umur 19 tahun adalah riap volume tegakan $=0,74 \mathrm{~m}^{3} \mathrm{ha}^{-1}$ tahun $^{-1}$, riap rata-rata diameter tegakan $=0,6 \mathrm{~cm}_{\text {tahun }}^{-1}$, dan riap rata-rata tinggi tegakan $=0,3 \mathrm{~m}$ tahun $^{-1}$.

3. Model regresi untuk menduga parameter tegakan jati di Takari adalah 1) $\mathrm{D}(\mathrm{cm})=5,52356+$ $0,08710^{\mathrm{X}}$, dan 2) $\mathrm{T}(\mathrm{m})=2,31488+0,18455^{\mathrm{X}}$. Untuk tegakan jati di Polen tahun 1997 adalah 1$)$ $\mathrm{D}(\mathrm{cm})=2,25149+0,19089^{\mathrm{X}}$, dan 2) $\mathrm{T}(\mathrm{m})=2,33788+0,15172^{\mathrm{X}}$. Dimana $:$ a) $\mathrm{X}=$ umur tegakan, b) $\mathrm{D}=$ diameter tegakan, dan c) $\mathrm{T}=$ tinggi tegakan.

4. Model regresi untuk menduga parameter tegakan cendana tahun 1976 adalah 1) $\mathrm{D}(\mathrm{cm})=6,5412+$ $\left.0,0192^{\mathrm{X}}, 2\right) \quad \log \mathrm{T}(\mathrm{m})=\log -14,6848+6,0541 \log \mathrm{X}$. Untuk tegakan cendana tahun 1987 adalah 1) $\mathrm{D}(\mathrm{cm})=6,9839+0,2140 \mathrm{X}, 2) \log \mathrm{T}(\mathrm{m})=\log -4,4230+3,6507 \log X$.

\section{DAFTAR PUSTAKA}

Alrasjid, H.1991. Faktor Kualitas Lahan Pembatas untuk Pertumbuhan Gmelina arborea. Bogor : Buletin Penelitian Hutan $540: 1-23$

Barrett. 1989. Sari Pustaka Cendana (Santalum album) di India, Alih bahasa oleh Sutarjo Suriamihardja. Kupang : Aisuli, 3: Tahun 1989, Unit Pelaksana Teknis di Nusa Tenggara Badan Litbang Kehutanan.

Darma, I.W. 2004. Pertumbuhan Awal Tanaman Jati (Tectona grandis L.f..) akibat Pemberian Pupuk Kandang dan Fosfat di Lahan Kering, Karangasem (tesis), Denpasar : Universitas Udayana.

Harbagung, D. Wahyono. 1994. Tatacara Pembuatan dan Pengukuran Petak Ukur Permanen (PUP). Informasi Teknis. Bogor : Pusat Penelitian dan Pengembangan Hutan dan Konservasi Alam.

Meyer, H.A., Recknagel and D.D, Stevenson. 1951. Forest Management. New York: The Ronald Press Company.

Bustomi, S. dan K. Soemarna. 1986. Tabel Isi Pohon Sementara Jenis Meranti (Shorea spp.) di KPH Bangkinang, Riau, Bogor. Laporan No,480, Pusat Penelitian dan Pengembangan Hutan.

Susila, I.W.W. 2004. Pendugaan Volume Pohon Hutan Tanaman Jati (Tectona grandis) umur 16 tahun di Kawasan Hutan Takari, Kupang, Kupang : Laporan Intern BP2KBNT. Tidak diterbitkan.

Rahayu, S., A.H. Wawo, M. Noordwijk, K. Hairiah. 2002. Cendana, Deregulasi dan Strategi Pengembangannya. Bogor : Word Agroforestry Centre - ICRAF.

Warsito, S.P. dan W. Andayani. 1987. Pengusahaan Hutan Tanaman Cendana. Makalah disampaikan pada diskusi cendana. Universitas Gadjah Mada, Yogyakarta 


\section{Lampiran 1}

HASIL ANALISIS REGRESI TERBAIK DARI 4 MODEL REGRESI (LINEAR, LOGARITHMA, KUADRATIK, DAN EKSPONENTIAL), RIAP JATI 1991 DI TAKARI, KUPANG

Dependent variable, MAID

Method, EXPONENT

Listwise Deletion of Missing Data

Multiple R , 60202

R Square , ,36243

Adjusted R Square ,31339

Standard Error $\quad, 08099$

Analysis of Variance:

DF Sum of Squares Mean Square

$\begin{array}{lrrr}\text { Regression } & 1 & , 04847274 & , 04847274 \\ \text { Residuals } & 13 & , 08526955 & , 00655920\end{array}$

$F=\quad 7,39004 \quad$ Signif $F=, 0176$

\begin{tabular}{lcccc} 
Variable & B SE B B Beta & T Sig T \\
& & \multicolumn{4}{c}{ Variables in the Equation } & \\
UMUR &,- 040196 &, 014786 &,- 602025 & $-2,718,0176$ \\
(Constant) & 1,942568 &, 233353 & $8,325,0000$
\end{tabular}

Dependent variable, MAIT

Method,, EXPONENT

Listwise Deletion of Missing Data

Multiple R ,68817

R Square $\quad, 47358$

Adjusted R Square , ,43308

Standard Error $\quad, 09169$

Analysis of Variance:

DF Sum of Squares Mean Square

Regression $1 \quad 09832229 \quad, 09832229$

Residuals $\quad 13 \quad$, 10929346 ,00840719

$F=11,69502 \quad$ Signif $F=, 0046$

\begin{tabular}{lcccc} 
Variable & B & \multicolumn{5}{c}{ SE B Briables in the Equation } & \\
& & & & \\
& 057249 &, 016740 &, 688170 & $3,420,0046$ \\
UMUR &, 014116 &, 110719 & $7,353,0000$
\end{tabular} 
Dependent variable, CAID

Listwise Deletion of Missing Data

Multiple R ,84798

R Square $\quad, 71908$

Adjusted R Square ,65665

Standard Error $\quad$,37379

Analysis of Variance:

DF Sum of Squares Mean Square

$\begin{array}{lccc}\text { Regression } & 2 & 3,2187639 & 1,6093819 \\ \text { Residuals } & 9 & 1,2574795 & , 1397199\end{array}$

$F=11,51863 \quad$ Signif $F=, 0033$

$\begin{array}{lccccc}\text { Variable } & \text { B } & \text { SE B } & \text { Beta } & \text { T Sig T } & \\ & & & & & \\ \text { UMUR } & -6,716735 & 1,621439 & -12,295522 & -4,142 & , 0025 \\ \text { UMUR } * * 2 & , 461767 & , 107904 & 12,702036 & 4,279,0021 \\ \text { (Constant) } & 24,885340 & 5,979688 & 4,162,0024\end{array}$

Dependent variable, CAIT

Method, QUADRATI

Listwise Deletion of Missing Data

Multiple R $\quad 94750$

R Square $\quad$,89776

Adjusted R Square ,87504

Standard Error ,36244

Analysis of Variance:

DF Sum of Squares Mean Square

Regression $2 \quad 10,380950 \quad 5,1904748$

$\begin{array}{llll}\text { Residuals } \quad 9 \quad 1,182264 & , 1313627\end{array}$

$F=\quad 39,51256 \quad$ Signif $F=, 0000$

\begin{tabular}{lcccc} 
Variable & B SE B Beta & T Sig T \\
& & \multicolumn{5}{c}{ Variables in the Equation } \\
UMUR & $-9,104978$ & 1,572198 & $-10,370155$ & $-5,791,0003$ \\
UMUR**2 &, 646850 &, 104627 & 11,070619 & $6,182,0002$ \\
(Constant) & 33,152123 & 5,798094 & $5,718,0003$
\end{tabular}

Dependent variable,, DIAMETER

Method, EXPONENT

Listwise Deletion of Missing Data

Multiple R , ,85953

R Square $\quad$,73879

Adjusted R Square ,71869

Standard Error $\quad, 07868$ 
Analysis of Variance:

DF Sum of Squares Mean Square

$\begin{array}{lrrr}\text { Regression } & 1 & , 22759270 & , 22759270 \\ \text { Residuals } & 13 & , 08046970 & , 00618998\end{array}$

$F=\quad 36,76794 \quad$ Signif $F=, 0000$

\begin{tabular}{lrrrr} 
Variable & B SE B & \multicolumn{4}{c}{ Beta } & T Sig T \\
& & & & \\
UMUR & 087100 &, 014364 &, 859528 & $6,064,0000$ \\
(Constant) & 5,523559 &, 644577 & $8,569,0000$
\end{tabular}

Dependent variable,, TINGGI

Method,, EXPONENT

Listwise Deletion of Missing Data

Multiple R , ,95343

R Square ,90904

Adjusted R Square ,90204

Standard Error $\quad$,08868

Analysis of Variance:

DF Sum of Squares Mean Square

$\begin{array}{lrrr}\text { Regression } & 1 & 1,0217083 & 1,0217083\end{array}$

Residuals $\quad 13 \quad, 022371 \quad, 0078644$

$F=129,91576 \quad$ Signif $F=, 0000$

\begin{tabular}{lrrrrr} 
Variable & \multicolumn{4}{c}{ B } & \multicolumn{4}{c}{ SE B Beta } & T Sig T \\
& & & & & \\
UMUR &, 184545 &, 016191 &, 953434 & $11,398,0000$ \\
(Constant) & 2,314884 &, 304490 & $7,602,0000$
\end{tabular}




\section{Lampiran 2}

HASIL ANALISIS REGRESI TERBAIK DARI 4 MODEL REGRESI (LINEAR, LOGARITHMA, KUADRATIK, DAN EKSPONENTIAL), RIAP JATI 1996 DI POLEN

Dependent variable, MAID

Method, LINEAR

Listwise Deletion of Missing Data

Multiple R , , 18839

R Square $\quad, 03549$

Adjusted R Square - -12526

Standard Error $\quad$,20904

Analysis of Variance:

DF Sum of Squares Mean Square

$\begin{array}{llll}\text { Regression } & 1 & , 00964691 & , 00964691 \\ \text { Residuals } & 6 & , 26218003 & 04369667\end{array}$

$F=\quad, 22077 \quad$ Signif $F=, 6550$

Variables in the Equation ------------------

$\begin{array}{lrccc}\text { Variable } & \text { B } & \text { SE B } & \text { Beta } & \text { T Sig T } \\ & & & & \\ \text { UMUR } & -, 044484 & , 094675 & -, 188386 & -, 470,6550 \\ \text { (Constant) } & 1,352742 & , 678598 & 1,993,0933\end{array}$

Dependent variable, MAIT

Method, QUADRATI

Listwise Deletion of Missing Data

Multiple R , 51215

R Square $\quad, 26230$

Adjusted R Square -,03278

Standard Error $\quad, 12557$

Analysis of Variance:

DF Sum of Squares Mean Square

$\begin{array}{lccc}\text { Regression } & 2 & , 02803094 & , 01401547 \\ \text { Residuals } & 5 & , 07883419 & , 01576684\end{array}$

$\begin{array}{llll}\text { Residuals } & 5 & 07883419 & , 01576684\end{array}$

$F=\quad, 88892 \quad$ Signif $F=, 4674$

Variables in the Equation

$\begin{array}{lccccc}\text { Variable } & \text { B } & \text { SE B } & \text { Beta } & \text { T Sig T } \\ & & & & \\ \text { UMUR } & -1,286467 & 1,302149 & -8,688961 & -, 988,3685 \\ \text { UMUR **2 } & , 087600 & , 092414 & 8,336730 & , 948,3867 \\ \text { (Constant) } & 5,451400 & 4,539522 & 1,201,2836\end{array}$




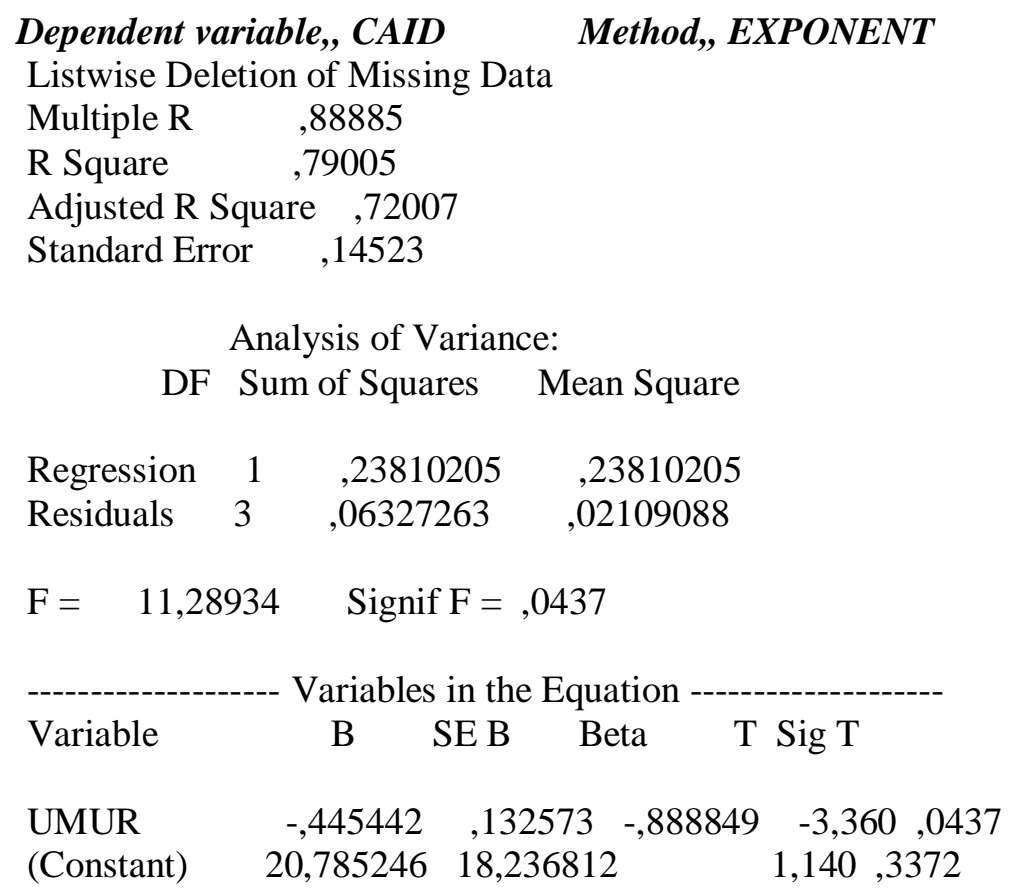

\section{Dependent variable, CAIT}

Method, LINEAR

Listwise Deletion of Missing Data

Multiple R , 93326

R Square $\quad$,87098

Adjusted R Square ,82797

Standard Error $\quad, 17544$

\section{Analysis of Variance:}

DF Sum of Squares Mean Square

$\begin{array}{llll}\text { Regression } & 1 & 62334785 & , 62334785\end{array}$

$\begin{array}{llll}\text { Residuals } & 3 & 093078022\end{array}$

$F=20,25157 \quad$ Signif $F=, 0205$

$\begin{array}{lrcccc}\text { Variable } & \text { B } & \text { SE B B Beta } & \text { T Sig T } & \\ \text { UMUR } & , 720733 & , 160157 & , 933261 & 4,500,0205 \\ \text { (Constant) } & -4,097800 & 1,059943 & -3,866,0306\end{array}$

Dependent variable,, DIAMETER

Method,, EXPONENT

Listwise Deletion of Missing Data

Multiple R ,38168

R Square $\quad, 14568$

Adjusted R Square ,00329

Standard Error $\quad$,21240 
Analysis of Variance:

DF Sum of Squares Mean Square

$\begin{array}{lccc}\text { Regression } & 1 & , 04615673 & , 04615673 \\ \text { Residuals } & 6 & , 27068045 & , 04511341\end{array}$

$F=\quad 1,02313 \quad$ Signif $F=, 3508$

Variables in the Equation

$\begin{array}{lrccc}\text { Variable } & \text { B } & \text { SE B } & \text { Beta } & \text { T Sig T } \\ \text { UMUR } & , 097304 & , 096198 & , 381680 & 1,011,3508 \\ \text { (Constant) } & 3,607658 & 2,487521 & 1,450,1972\end{array}$

Dependent variable, TINGGI

Method,, EXPONENT

Listwise Deletion of Missing Data

Multiple R ,39647

R Square $\quad, 15719$

Adjusted R Square ,01672

Standard Error $\quad, 15712$

Analysis of Variance:

DF Sum of Squares Mean Square

$\begin{array}{lccc}\text { Regression } & 1 & , 02762361 & , 02762361 \\ \text { Residuals } & 6 & 14811476 & 02468579\end{array}$

$\mathrm{F}=\quad 1,11901 \quad$ Signif $\mathrm{F}=, 3309$

$\begin{array}{lrcccc}\text { Variable } & \text { B } & \text { SE B } & \text { Beta } & \text { T Sig T } \\ \text { UMUR } & , 075275 & , 071160 & , 396467 & 1,058,3309 \\ \text { (Constant) } & 3,220560 & 1,642644 & 1,961,0976\end{array}$




\section{Lampiran 3}

HASIL ANALISIS REGRESI TERBAIK DARI 4 MODEL REGRESI (LINEAR, LOGARITHMA, KUADRATIK, DAN EKSPONENTIAL), RIAP JATI 1997 DI POLEN

Dependent variable, MAID

\section{Method, EXPONENT}

Listwise Deletion of Missing Data

Multiple R , 28442

R Square $\quad$,08089

Adjusted R Square -,05041

Standard Error $\quad, 07326$

Analysis of Variance:

DF Sum of Squares Mean Square

$\begin{array}{lccc}\text { Regression } & 1 & , 00330647 & , 00330647 \\ \text { Residuals } & 7 & , 03756759 & , 00536680\end{array}$

$F=\quad, 61610 \quad$ Signif $F=, 4582$

\begin{tabular}{lrrrr} 
Variable & B & \multicolumn{4}{c}{ SE B Beta } & T Sig T \\
& & & & \\
UMUR &, 023475 &, 029908 &, 284419 & $, 785,4582$ \\
(Constant) & 1,034482 &, 187344 & $5,522,0009$
\end{tabular}

\section{Dependent variable, MAIT Method, QUADRATI}

Listwise Deletion of Missing Data

Multiple R ,71928

R Square $\quad, 51737$

Adjusted R Square ,35649

Standard Error $\quad, 06490$

Analysis of Variance:

DF Sum of Squares Mean Square

$\begin{array}{llll}\text { Regression } 201354598 & 02709197 \quad, 007\end{array}$

$\begin{array}{llll}\text { Residuals } & 6 & 02527307 & , 00421218\end{array}$

$\mathrm{F}=\quad 3,21591 \quad$ Signif $\mathrm{F}=, 1124$

Variables in the Equation

$\begin{array}{lccccc}\text { Variable } & \text { B } & \text { SE B } & \text { Beta } & \text { T Sig T } \\ & & & & \\ \text { UMUR } & -1,368364 & , 551343 & -14,647263 & -2,482,0477 \\ \text { UMUR **2 } & , 112617 & , 045892 & 14,482391 & 2,454 & , 0495 \\ \text { (Constant) } & 5,061500 & 1,629441 & 3,106 & , 0209\end{array}$


Dependent variable, CAID

Listwise Deletion of Missing Data

Multiple R ,70832

R Square $\quad, 50171$

Adjusted R Square ,37714

Standard Error $\quad$,36980

Analysis of Variance:

DF Sum of Squares Mean Square

$\begin{array}{lccc}\text { Regression } & 1 & , 55078529 & , 55078529 \\ \text { Residuals } & 4 & , 54701993 & , 13675498\end{array}$

$F=\quad 4,02753 \quad$ Signif $F=, 1152$

\begin{tabular}{lcccc} 
Variable & \multicolumn{5}{c}{ B } & SE B Bables in the Equation & Beta & T Sig T \\
& & & & \\
UMUR &, 605962 &, 301944 &, 708318 & $2,007,1152$ \\
(Constant) &, 044967 &, 074985 & $, 600,5810$
\end{tabular}

Dependent variable, CAIT

Method, LINEAR

Listwise Deletion of Missing Data

Multiple R $\quad$,98314

R Square $\quad$,96656

Adjusted R Square ,95820

Standard Error $\quad, 15235$

Analysis of Variance:

DF Sum of Squares Mean Square

$\begin{array}{llll}\text { Regression } & 1 & 2,6832256 & 2,6832256\end{array}$

$\begin{array}{llll}\text { Residuals } \quad 4,0232091 & 0928366\end{array}$

$F=115,61070 \quad$ Signif $F=, 0004$

Variables in the Equation

$\begin{array}{lrcccc}\text { Variable } & \text { B } & \text { SE B } & \text { Beta } & \text { T Sig T } \\ & & & & \\ \text { UMUR } & 1,337467 & , 124390 & , 983137 & 10,752,0004 \\ \text { (Constant) } & -6,436400 & , 686964 & -9,369,0007\end{array}$

Dependent variable, DIAMETER

Method, EXPONENT

Listwise Deletion of Missing Data

Multiple R $\quad, 92827$

R Square $\quad, 86169$

Adjusted R Square ,84194

Standard Error $\quad, 07080$ 
Analysis of Variance:

DF Sum of Squares Mean Square

$\begin{array}{lccc}\text { Regression } & 1 & , 21862380 & , 21862380 \\ \text { Residuals } & 7 & , 03509018 & , 00501288\end{array}$

$F=\quad 43,61239 \quad$ Signif $F=, 0003$

Variables in the Equation

$\begin{array}{lrrrcr}\text { Variable } & \text { B } & \text { SE B } & \text { Beta } & \text { T Sig T } \\ & & & & \\ \text { UMUR } & , 190886 & , 028905 & , 928275 & 6,604,0003 \\ \text { (Constant) } & 2,251494 & , 394071 & 5,713,0007\end{array}$

\section{Dependent variable,, TINGGI}

Method,, EXPONENT

Listwise Deletion of Missing Data

Multiple R ,85748

R Square $\quad, 73528$

Adjusted R Square ,69746

Standard Error $\quad, 08428$

Analysis of Variance:

DF Sum of Squares Mean Square

$\begin{array}{llll}\text { Regression } & 1 & , 13811408 & , 13811408 \\ \text { Residuals } & 7 & , 04972510 & , 00710359\end{array}$

$F=\quad 19,44287 \quad$ Signif $F=, 0031$

Variables in the Equation

$\begin{array}{lrrrrr}\text { Variable } & \text { B } & \text { SE B } & \text { Beta } & \text { T Sig T } \\ & & & & \\ \text { UMUR } & , 151720 & , 034408 & , 857484 & 4,409,0031 \\ \text { (Constant) } & 2,337875 & , 487102 & 4,800,0020\end{array}$




\section{Lampiran 4}

MODEL-MODEL REGRESI TERPILIH TEGAKAN CENDANA TAHUN 1976 DI ALOR

Dependent variable.. D

Method.. EXPONENT

Listwise Deletion of Missing Data

Multiple R $\quad$,98102

R Square $\quad$,96241

Adjusted R Square ,92482

Standard Error $\quad, 00820$

Analysis of Variance:

DF Sum of Squares Mean Square

Regression $1 \quad 00172285 \quad, 00172285$

$\begin{array}{llll}\text { Residuals } & 1 & 1 & 00006730\end{array}$

$F=25,60106 \quad$ Signif $F=, 1242$

Variables in the Equation

\begin{tabular}{lcccl} 
Variable & B & SE B & Beta & T Sig T \\
& & & \\
X & 019214 & 003797 &, 981024 & $5,060,1242$ \\
(Constant) & \multicolumn{2}{c}{$6,546150 \quad, 729845$} & $8,969,0707$
\end{tabular}

Dependent variable.. T

Method.. LOGARITH

Listwise Deletion of Missing Data

Multiple R $\quad, 97078$

R Square $\quad$,94242

Adjusted R Square , ,88484

Standard Error , 10942

Analysis of Variance:

DF Sum of Squares Mean Square

Regression 1,1959505032

Residuals $1,01197185 \quad, 01197185$

$F=16,36759 \quad$ Signif $F=, 1543$ 
Variables in the Equation

$\begin{array}{lcccc}\text { Variable } & \text { B } & \text { SE B } & \text { Beta } & \text { T Sig T } \\ \text { X } & 6,054063 & 1,496424 & , 970784 & 4,046,1543 \\ \text { (Constant) } & -14,684756 & 5,055058 & -2,905,2111\end{array}$

\section{Dependent variable.. MAID}

Method.. LOGARITH

Listwise Deletion of Missing Data

Multiple R $\quad$,97100

R Square , 94284

Adjusted R Square ,88567

Standard Error $\quad, 00290$

Analysis of Variance:

DF Sum of Squares Mean Square

Regression $1 \quad, 00013841 \quad, 00013841$

Residuals $1 \quad 00000839 \quad, 00000839$

$F=16,49384 \quad$ Signif $F=, 1537$

Variables in the Equation

$\begin{array}{llllll}\text { Variable } & \text { B } & \text { SE B } & \text { Beta } & \text { T Sig T }\end{array}$

$\begin{array}{lllllll}\text { X } & -, 160903 & 039619 & -, 970998 & -4,061\end{array}$

$\begin{array}{llllll}\text { (Constant) , 133837 } & \text { 935637 }\end{array}$

Dependent variable.. MAIT

Method.. LINEAR

Listwise Deletion of Missing Data

Multiple R $\quad, 18168$

R Square $\quad$,03301

Adjusted R Square -,93399

Standard Error $\quad, 00401$

Analysis of Variance:

DF Sum of Squares Mean Square

Regression $1 \quad 00000055 \quad, 00000055$

$\begin{array}{llll}\text { Residuals } & 1 & 1 & 00001607\end{array}$

$F=\quad, 03413 \quad$ Signif $F=, 8837$ 
Jurnal Penelitian Hutan Tanaman

Vol. 6 No.3, April 2009, 157-185

Variables in the Equation

\begin{tabular}{lccrr} 
Variable & B & SE B & Beta & T Sig T \\
X & \multicolumn{1}{c}{000343} &, 001856 &, 181677 & $, 185,8837$ \\
(Constant) &, 186443 &, 054485 & $3,422,1810$
\end{tabular}




\section{Lampiran 5}

MODEL-MODEL REGRESI TERPILIH TEGAKAN CENDANA TAHUN 1987 DI ALOR

Dependent variable.. D

Method.. LINEAR

Listwise Deletion of Missing Data

Multiple R $\quad$,99723

R Square $\quad$,99447

Adjusted R Square ,98895

Standard Error $\quad, 03446$

Analysis of Variance:

DF Sum of Squares Mean Square

Regression $1 \quad 21368840 \quad, 21368840$

Residuals $\quad 1 \quad 00118768 \quad, 00118768$

$F=179,92089 \quad$ Signif $F=, 0474$

Variables in the Equation

$\begin{array}{lllll}\text { Variable } & \text { B } & \text { SE B } & \text { Beta } & \text { T Sig T }\end{array}$

$\begin{array}{llllll}\text { X } & \text { 213987, 0474 }\end{array}$

(Constant) $\quad 6,983789,277236 \quad 25,191,0253$

Dependent variable.. $T \quad$ Method.. LOGARITH

Listwise Deletion of Missing Data

Multiple R $\quad$,99031

R Square , 98071

Adjusted R Square ,96142

Standard Error $\quad, 06311$

Analysis of Variance:

DF Sum of Squares Mean Square

Regression 10248766

Residuals $1,00398264 \quad, 00398264$

$F=50,84256 \quad$ Signif $F=, 0887$ 


$\begin{array}{lcccc}\text { Variable } & \text { B } & \text { SE B } & \text { Beta } & \text { T Sig T } \\ \text { X } & 3,650712 & , 511993 & , 990308 & 7,130,0887 \\ \text { (Constant) } & -4,423043 & 1,459675 & -3,030,2029\end{array}$

Dependent variable.. MAID

Method.. LOGARITH

Listwise Deletion of Missing Data

Multiple R $\quad$,99774

R Square ,99549

Adjusted R Square ,99099

Standard Error $\quad, 00334$

Analysis of Variance:

DF Sum of Squares Mean Square

Regression $1 \quad, 00246133 \quad, 00246133$

Residuals $1,00001114,00001114$

$\mathrm{F}=220,88295 \quad$ Signif $\mathrm{F}=, 0428$

Variables in the Equation

\begin{tabular}{lrccl} 
Variable & B & SE B & Beta & T Sig T \\
X &,- 402498 &, 027082 &,- 997744 & $-14,862,0428$ \\
(Constant) & \multicolumn{2}{c}{1,766222} &, 077210 & $22,875,0278$
\end{tabular}

Dependent variable.. MAIT

Method.. LINEAR

Listwise Deletion of Missing Data

Multiple R ，97859

R Square $\quad$,95764

Adjusted R Square ,91528

Standard Error $\quad, 00347$

Analysis of Variance:

DF Sum of Squares Mean Square

Regression $1 \quad 00027215 \quad, 00027215$

Residuals $1,00001204,00001204$

$\mathrm{F}=22,60582 \quad$ Signif $F=, 1320$ 
Variables in the Equation

\begin{tabular}{lrccc} 
Variable & B & SE B & Beta & T Sig T \\
X &,- 007637 &, 001606 &,- 978590 & $-4,755,1320$ \\
(Constant) & \multicolumn{2}{c}{, 478040} &, 027912 & $17,127,0371$
\end{tabular}

